\title{
The Feed Requirements of Adult Red Deer
}

R. C. MULLEY

University of Western Sydney, Richmond, NSW, Australia r.mulley@uws.edu.au

\begin{abstract}
This paper reviews the feeding requirements of adult red deer from nutritional, management and ecological perspectives. Particular emphasis is placed on the need to balance production objectives in the context of ecological sustainability.

Topics such as feeding behaviour, feeding management, the relationship of body condition score to nutritional sufficiency, daily and seasonal feed intake requirements, and pasture species selection are also presented. The marketability of venison and the longterm acceptance of deer farming will be largely shaped by consumer perception of the animal welfare implications of production techniques, the ecological impact of production and an industry image that reflects social responsibility. Development of efficient feeding systems for farmed deer will impact on all of these areas.
\end{abstract}

\section{Introduction}

A full understanding of the feed requirements of adult red deer combines information on seasonal voluntary feed intake (VFI), growth and seasonal production potential which determines metabolisable energy (ME) requirements, diet selection, animal behaviour, environmental constraints, pasture and other feed availability and a range of management choices and marketing opportunities. In short, feeding a production animal is not just about providing feed for maintenance and growth, it involves careful management and planning of a farming system. This is particularly true when considering the feed requirements of adult red deer because of; the highly seasonal nature of feed demand for both hinds and stags (Suttie 1987; Drew 1996; Barry et al. 1998); increasing evidence that more careful management of the forage species available to deer can increase production efficiency in this species (Barry et al. 1998, Barry et al. 1999); and the need for ecologically benign farming practices to meet local and international expectations for land use and deer welfare in modern deer farming systems (Pearse \& Drew 1998). This paper will address aspects of feeding management of adult red deer in the context of a farming system so that feed requirement per se is not isolated from the ecology of the farm, the social acceptability of farming deer and the economic viability imperative of farming.

\section{Nutritional Requirements}

There is an important difference between feeding deer, and providing them with their nutritional requirements. Some deer farmers provide feed for deer without regard for its nutritive value, the physiological requirement of the animal or the stage of the production cycle. For high performance year-round, feeds with an optimal combination of ME, protein and trace elements content must be provided and matched with stage of production and time of year requirements. Drew (1996) provided an excellent summary of the seasonal energy requirements and requirements for maintenance and growth for red deer and hybrids, and this should be referred to, (Appendix I). In summary, mature stags $(230-250 \mathrm{~kg})$ require on average $19,35,42$ and $28 \mathrm{MJME} /$ day in autumn, winter, spring and summer respectively. Note that stags will only consume about half of their requirement during autumn (the rut) even when high quality feed is available. Drew (1996) also predicted that mature hinds (115-130 kg) require on average 27, 26, 28 and $49 \mathrm{MJME} /$ day in autumn, winter, spring and summer respectively. More recently, Asher et al. (2000) demonstrated a pattern of continuous increase in energy requirement in late-pregnancy, with VFI increasing from $23 \mathrm{MJME} /$ day in week 18 (130 days gestation) to 31 MJME/day in week 30 (210 days gestation). These data convert to $1.8-2 \mathrm{~kg} / \mathrm{hd} /$ day of dry matter intake (DMI) at week 18 to $2.6-2.8 \mathrm{~kg} \mathrm{DM}$ hd/day at week 30 . During the 12 weeks of continuous feed monitoring, hinds in that study increased average body condition score (BCS) from 3 to 3.5, with some individual animals achieving BCS of > 4.0. In the same study, hinds deprived of adequate nutrition in late pregnancy (e.g. $70 \%$ ad lib intake) had a significantly longer gestation length compared with hinds that had unrestricted intake of a pelleted ration containing $11 \mathrm{MJME} / \mathrm{kg} \mathrm{DM}$ and $14 \%$ crude protein. However, the authors warned that luxury feeding in late-pregnancy may be associated with dystocia in red deer hinds, although there was no such occurrence in their trial.

The pattern of feed intake in late-pregnancy in red deer is similar to that shown for fallow deer (Mulley et al. 2000). It is likely that the pattern of feed intake during lactation in red deer is also similar to that in fallow deer (Mulley et al. 2000) though exact data for lactation has not been collected for red deer hinds. This is important and necessary data to collect for red deer because Mulley et al. (2000) showed that the ME requirement during the first 12 weeks of lactation in fallow deer accounted for $60 \%$ of the annual ME requirement. It is likely to be 
similar for red deer hinds and this has major implications for planning feed requirements in summer on commercial deer farms.

Wilson \& Grace (2000) and Beatson et al. (2000) provided information and discussion on the importance and levels of a range of trace elements in commercial deer herds in New Zealand. Their data highlight the need for monitoring of copper, selenium and cobalt levels in deer herds, with low copper status in particular possibly limiting production at the herd and individual animal levels. Wilson \& Grace (2000) suggested that current data does not allow determination of a reference value for copper in relation to growth and production in farmed deer. Further, they indicated that to achieve production responses, blood and liver copper concentration must be considerably below the currently proposed adequate concentration of $8 \mu \mathrm{mol} / \mathrm{L}$ and liver copper concentration of $100 \mu \mathrm{mol} / \mathrm{kg}$ fresh tissue.

Protein requirements for adult red deer can range from $12-16 \%$ depending on stage of production cycle, with higher requirements in spring and summer for both stags and hinds. Waghorn and Bar ry (1987) indicated that most New Zealand pastures contain $12-25 \%$ crude protein and that $75-85 \%$ of crude plant protein is digested. During periods of drought (summer or winter) both crude protein and metabolisable energy concentration may be inadequate in available feed, requiring supplementation.

\section{Feeding Management}

Red deer can be fed entirely on pasture, entirely on grain, or a combination of concentrates and pasture, and meet production objectives. Leafy, growing pasture with a sward height greater than $10 \mathrm{~cm}(2000 \mathrm{~kg} \mathrm{DM} / \mathrm{ha})$ is necessary to ensure adequate feed intake for growth although adult hinds and stags can be maintained on swards as low as $5 \mathrm{~cm}(1400 \mathrm{~kg} \mathrm{DM} / \mathrm{ha})$ with supplementation if necessary (Hodgson 1999). Pastures in a growth phase following harvesting or grazing have higher metabolisable energy (ME) and crude protein content, and regenerate more quickly if not grazed below $1000 \mathrm{~kg} \mathrm{DM} / \mathrm{ha}$. Waghorn \& Barry (1987) described the decline in perennial ryegrass digestibility with stage of growth, and this species is indicative of other grasses as well. Young, leafy and late vegetative pasture growth prior to flowering provides the highest quality pasture feed for deer. Pastures g razed at these stages of growth provide metabolisable energy content in excess of 10.5 MJME $/ \mathrm{kg} \mathrm{DM}$, and are $>75 \%$ digestible. There is a rapid decline of ME value with increasing maturity of plant growth, which approximates $1 \mathrm{MJME} / \mathrm{kg}$ DM as plants develop through early, mid and late flowering, dry grass and dry stalks stages of growth (PROGRAZE 1995).

Deer can be fed completely on grain rations, although lactating hinds give low milk yield on grain only diets and it is recommended that $20 \%$ of the DMI as hay be included in the diet of these stock (Mackay 1995). Barley, oats and lupins are suitable grains if locally available, but cost versus production benefit remains a management decision. Choice of feed purchases should be based on the cost per megajoule of energy, and selected feed types checked for the possibility of chemical residues or unwanted weed species. Silage and good quality, leafy hay are also good supplementary feeds that red deer utilise well.

\section{Feeding Behaviour}

A study of feeding behaviour patterns for red deer hinds (Mulley unpublished) confirmed a diurnal pattern in which dawn and dusk were high feeding activity times, as was a period between midnight and 2 a.m. Several shorter feeding periods also occurred throughout the day and night. Feeding events were spaced at 2-3 hour intervals when feed was available. Rumen outflow rate and feed digestibility will change depending on how often an animal feeds, and this can have significant effects on production in ruminants. These data need to be considered in times of drought, when feeding on alternate days is thought by many to be a satisfactory practice. Pasture alone does not support $100 \%$ of deer feed requirements in New Zealand on deer farms with high stock density. Supplementary feeding is needed when deer should not lose any more weight and the pasture is no longer capable of supporting 30 percent of nutritional requirements (Mackay 1995). However, feed supplements need to be offered well before this for hinds, e.g. when BCS falls to below 2.5, to avoid adverse production consequences. Body condition in older stags may fall below 2 in the rut, even when high quality supplements are offered.

There has been a significant amount of research data collected on red deer foraging behaviour, but little of this information has been used to assist development of feeding strategies for farmed deer. Information on feed preference and natural feeding patterns (e.g. CluttonBrock et al. 1982a,b) needs to be combined with the morphophysiological specialisation and adaptation of the digestive physiology of red deer (Hoffman 1985) and testing of alternative pasture, forage and browse species to add finesse to the efficiency of growth and development in farmed deer. Recent studies by Hodgson (1999) address grazing behaviour of individual animals on improved pastures for parameters such as comparative grazing preference between grasses and legumes, bite size and rate of herbage intake in relation to sward height, and similar work should also be conducted on browse species and forages with higher concentration of condensed tannins and phenolics, to assess production opportunities using these species in combination with grasses and pasture legume species. 


\section{Alternative Pasture Species}

Red deer are classified as "intermediate" feeders according to their digestive physiology (Hoffman 1985) and will select and digest browse material when given the opportunity, in addition to grasses, and legumes. Accordingly, deer can utilise more efficiently forages and browse with higher contents of phenolics and condensed tannins for maintenance and growth, than other domesticated species such as sheep and cattle. Recent work on a range of tree species (Hartley et al. 1994), and alternative pasture species such as lotus, chicory and red clover (Barry et al. 1993, 1999, 2000), shows that they offer substantial production advantages over traditional improved pasture mixes such as rye grass/w hite clover when fed to red deer. Some of these plant species (e.g. chicory) contain compounds such as condensed tannins and sesquiterpene lactones, and there is some evidence that these compounds may assist deer health by reducing burdens of internal parasites (Barry et al.2001). If red clover is available, caution should be exercised with its use in adult hinds prior to the rut to avoid possible reproductive failure due to the high oestrogenic content of the plant even though there is little evidence that deer are as susceptible as sheep to this problem.

The evidence so far confirms that pasture species previously used effectively for the production of sheep and cattle are not the most effective for deer. In addition to genetic improvement, it is likely that manipulation of the diet of farmed deer will lead to the most significant advances in production efficiency in this domesticant over the next decade.

\section{Body Condition Score}

While the gross feed requirements of red deer are now defined, the BCS of an animal is an important measure of nutritional sufficiency over time, and remains one of the most useful practical tools in animal production. Audige et al. (1998) developed a 5 point BCS for red deer, with half unit increments. Tuckwell et al. (2000) produced a similar 5 point system and related live animal description with carcass measurements to develop a common industry wide system for carcass description in Australia. The broad descriptors are as follows:

BCS 1: Animals in this categ ory are considered to be emaciated with no fat cover. The pelvis, ribs and spine are prominent with no fat cover over the rump, which is concave in appearance. Carcass measurements at the GR site show no fat with tissue depth less than $5 \mathrm{~mm}$.

BCS 2: Animals in this cate gory are lean with minimal fat cover. The pelvis, ribs and spine are still prominent but appear rounded rather than sharp. Carcass measurements at the GR site show fat depth less than $2 \mathrm{~mm}$ with tissue depth at least 5 , but less than $10 \mathrm{~mm}$.
BCS 3: Animals in this category are considered to have ideal fat cover. The pelvis, ribs and spine are not readily distinguished and the rump area is flat. Carcass measurements at the GR site show fat depth of at least 2 but less than $4 \mathrm{~mm}$ with tissue depth at least 10 but less than $15 \mathrm{~mm}$.

BCS 4: Animals in this category are considered to be fat with rounded pelvis and rump and with the spine covered by fat. Carcass measurements at the GR site show fat depth of at least 4 but less than $6 \mathrm{~mm}$ with tissue depth at least 15 but less than $20 \mathrm{~mm}$. Some trimming of carcass fat will be necessary.

BCS 5: Animals in this category are considered to be over fat with a pelvis concealed by fat, a very convex rump, and a spine hard to palpate. Carcass measurements at the GR site show fat depth of $6 \mathrm{~mm}$ or more with tissue depth $20 \mathrm{~mm}$ or more. Excessive trimming of carcass fat will be required.

The rate at which BCS increases depends on the quality of feed and level of ME intake above maintenance level that is consumed. To achieve an increase of 1 BCS usually takes several weeks for red deer, even on good quality pasture. Body condition influences many aspects of deer production and profitability, including reproductive performance, susceptibility to disease and financial returns from processed animals, and is a more important indicator of nutritional status than live weight. Management of daily feed intake in a commercial deer herd, whether stags or hinds, should be adjusted according to average herd BCS and production target objectives. A fall in average BCS may indicate the need to initiate supplementary feeding.

\section{Ecologically Based Management Practices}

Most modern deer farming systems have become intensive, allowing strategic feeding for production and genetic improvement programs (Pearse \& Drew 1998). At the same time there is an increasing need for farmers to balance natural resource management and viable production systems within the context of ecological agriculture. Questions arise such as: Can deer be run at ecologically benign levels and still be profitable? Should producers have an ecological conscience? Pearse \& Drew (1998) assert that as the deer industry evolves, more attention must be paid to the ecological impact of deer farming in terms of animal and land welfare, product image and sustainable land use.

The environmental impact of feed production for livestock can be substantial, and combined with stocking rates above the natural carrying capacity of the land, can induce rapid land degradation. Supplementary feeding is used to increase stocking rates, balance rations, (particularly trace elements) and to assist in habituation (Haigh 1992), and has the potential to spare pastures 
from damage when conditions may be wet and muddy, when grass is not growing during the winter, or when stock density exceeds carrying capacity. However, the ecological risks associated with introducing supplements from outside the farm include introduction of weed and grass species, chemical contaminants, ground spoilage from rotting, un-eaten plant material, and microbial invaders such as fungi. Intensively managed production systems can result in water spoilage and erosion which affects downstream users, and in many places legislation is now in place to assist in preservation of environmental characteristics. Sustainable land-use practices may cost more and these costs should be built into gross margin calculations. It is economic irrationalism not to put a value on soil loss, salinity, nutrient loss and other environmental degradation.

Along with animal welfare, questions associated with the ecological impact of production increasingly shape consumer preference, and current and future efforts by the deer industry to proactively enhance landscape, develop more efficient feeding systems, and optimise the plant/animal interface will convey an image of social responsibility. Feeding systems more suited to the requirements and physiology of deer are emerging, but must combine with benign environmental impact to gain approval. A balance between an efficient production system, an approving social system, and economic via bility will ensure a sustainable deer industry.

\section{REFERENCES}

Asher, G.W.; Mulley, R.C.; O’Neill, K.T.; Scott, I.C. 2000. Studies on the nutritional requirements of adult red deer hinds during late pregnancy. In: Proceedings $17^{\text {th }}$ Conference New Zealand Veterinary Association Deer Branch, Queenstown, New Zealand.

Audige, L.; Wilson, P.R.; Morris, R.S. 1998. A body condition score system and its use for farmed red deer hinds. New Zealand Journal of Agricultural Research 41: 545-553.

Barry, T.N.; Moylan, A.L.; Wilson, P.R.; LopezVillalobos, N.; Schreurs, N.M.; Duncan, A.J. 2001. Chicory as an alternative forage for deer health. In: Proceedings $18^{\text {th }}$ Conference New Zealand Veterinary Association Deer Branch, Palmerston North, New Zealand.

Barry, T.N.; Wilson, P.R.; Hodgson, J; Kusmartono, X. 1993. Development of special purpose forage systems for deer production. In: Proceedings $10^{\text {th }}$ Conference New Zealand Veterinary Association Deer Branch, Palmerston North, New Zealand.

Barry, T.N.; Wilson, P.R.; Kemp, P.D. 1999. Responses in deer production to alternative pasture species. In: Proceedings $16^{\text {th }}$ Conference New Zealand Veterinary Association Deer Branch, Hastings, New Zealand.
Barry, T.N.; Wilson, P.R.; Kemp P.D. 2000. Feeding value of forages for venison production. AsiaAustralasian Journal of Animal Science 13C: 48-50.

Barry, T.N; Wilson, P.R.; Semiadi, G. 1998. Growth, voluntary food intake and digestion in farmed temperate and tropical deer. Acta Veterinaria Hungarica 46: 369-380.

Beatson, N.S.; Judson, H.G.; Campbell, A.C.; Wilson, P.R. 2000. Trace element data from the Deermaster Project. In: Proceedings $17^{\text {th }}$ Conference New Zealand Veterinary Association Deer Branch, Queenstown, New Zealand.

Clutton-Brock, T.H.; Guinness, F.E.; Albon, S.D.; 1982a. Red deer: behaviour and ecology of the two sexes. University of Chicago Press, Chicago, USA.

Clutton-Brock, T.H.; Iason, G.R.; Albon, S.D.; Guinness, F.E. 1982b. Effects of lactation on feeding behaviour and habitat use in wild red deer hinds (Cervus elaphus) in England. Journal of Zoology 198: 227-236.

Drew, K.R. 1996. Deer nutritional requirements. In: Proceedings $13^{\text {th }}$ Conference New Zealand Veterinary Association Deer Branch, Timaru, New Zealand.

Haigh, J.C. 1992. Requirements for managing farmed deer. In: The biology of deer. Ed. Brown, R.D. Springer-Verlag, New York.

Hartley, S.; Duncan, A.J.; Iason, G.R.; Staines, B.W. 1994. The effect of trace morphology and chemical composition on the feeding behaviour of red deer (Cervus elaphus). In: Recent developments in deer biology. Eds. Milne, J.A.; Moredun. Research Institute, Edinburgh, U.K.

Hodgson, J. 1999. The animal/pasture interface in deer grazing systems. In: Proceedings $16^{\text {th }}$ Conference New Zealand Veterinary Association Deer Branch, Hastings, New Zealand.

Hoffman, R.R. 1985. Digestive physiology of the deertheir morphophysiological specialisation and adaptation. In: Biology of Deer Production, Eds. Fennessy, P.F.; Drew, K.R. The Royal Society of New Zealand, Bulletin 22. 393-409.

Mackay, B.I. 1995. Drought management of deer. Australian Deer Farming 6: 22-27.

Mulley, R.C.; Flesch, J.S.; Asher, G.W. 2000. Energy intake of farmed fallow deer of 2 genotypes during pregnancy, lactation and growth to slaughter weight. In: Proceedings $17^{\text {th }}$ Conference New Zealand Veterinary Association Deer Branch, Queenstown, New Zealand.

Pearse, A.J.; Drew, K.R. 1998. Ecologically sound management: Aspects of modem sustainable deer farming systems. Acta Veterinaria Hungarica 46: 315-328.

PROGRAZE (1995) Livestock production from 
pasture. NSW Agriculture, Or ange, Australia.

Suttie, J.M. 1987. Deer growth and nutrition. In: Proceedings $4^{\text {th }}$ Conference New Zealand Veterinary Association Deer Branch, Dunedin, New Zealand.

Tuckwell, C.; Mulley, R.C.; Flesch, J.S.; Hansen, A; McKay, B. 2000. Australian body condition scoring chart for red deer. Rural Industries Research and Development Corporation, Canprint, Canberra, Australia.
Waghorn, C.G.; Barry, T.N. 1987. Pasture as a nutrient source. In: Feeding livestock on pasture. Ed. Nicol, A.M. N.Z. Society Animal Production Occasional Publication 10.

Wilson, P.R.; Grace, N. 2000. A re-evaluation of trace element reference values for farmed deer in New Zealand. In: Proceedings $17^{\text {th }}$ Conference New Zealand Veterinary Association Deer Branch, Queenstown, New Zealand.

Appendix 1: Daily feed requirements for mature deer (from Drew 1996).

\begin{tabular}{|c|c|c|c|c|}
\hline & \multicolumn{4}{|c|}{ Energy requirement (MJ ME/day) } \\
\hline & Autumn & Winter & Spring & Summer \\
\hline $\begin{array}{l}\text { Stags } \\
\text { NZ Red } \\
\text { Elk x Red } \\
\text { Elk or Wapiti }\end{array}$ & $\begin{array}{l}19 \\
25 \\
34\end{array}$ & $\begin{array}{l}35 \\
47 \\
62\end{array}$ & $\begin{array}{l}42 \\
56 \\
71\end{array}$ & $\begin{array}{l}38 \\
51 \\
66\end{array}$ \\
\hline $\begin{array}{l}\text { Hinds } \\
\text { NZ Red } \\
\text { Elk x Red } \\
\text { Elk or Wapiti }\end{array}$ & $\begin{array}{l}27 \\
48 \\
64\end{array}$ & $\begin{array}{l}26 \\
46 \\
61\end{array}$ & $\begin{array}{l}28 \\
50 \\
67\end{array}$ & $\begin{array}{c}49 \\
85 \\
120\end{array}$ \\
\hline
\end{tabular}

